\title{
XLIV. Some account of an Orang Outang of remarkable height found on the Island of Sumatra; together with a description of certain remains of this animal, presented to the Asiatic Society by Capt. Cornfoot, and at present contained in its museum
}

\section{Clarke Abel M.D. F.R.S.}

To cite this article: Clarke Abel M.D. F.R.S. (1827) XLIV. Some account of an Orang Outang of remarkable height found on the Island of Sumatra; together with a description of certain remains of this animal, presented to the Asiatic Society by Capt. Cornfoot, and at present contained in its museum , Philosophical Magazine Series 2, 1:3, 213-219, DOI: $10.1080 / 14786442708674276$

To link to this article: http://dx.doi.org/10.1080/14786442708674276

Published online: 10 Jul 2009.

Submit your article to this journal

山 Article views: 2 
verifying the accuracy of the above calculations. Venus is at this time approaching very near the point of her greatest elongation, and will pass the meridian about 32 minutes before the time of visible conjunction, at an altitude of about $16^{\circ} 51^{\prime}$ above the horizon of Greenwich.

Epping, Jan. 6th, 1827.

Yours truly,

Tiomas Sourre.

XLIV. Some Account of an OrangOutang of remarkable Height found on the Island of Sumatra; together with a Descriptions of certain Remains of this Animal, presented to the Asiatic Society by Capt. Cornfoot, and at present contained in its Museum. By Clarke Abel, M.D.F.R.S. \&c. \&c., and Member of the Asiatic Society of Calcutta*.

$\mathrm{N}$ the paper which I had the honour of reading to the Asiatic

Society on the evening of the 5th of January last, I endeavoured to be as comprehensive as possible, in relation to the published histories of large man-like apes, and to the many speculations of philosophers respecting them; and in order the better to accomplish my purpose, I divided my subject under the following heads: ' First, I gave an account of what particulars I had been able to collect of the circumstances which attended the capture of the Sumatran animal: Secondly, I gave the amplest description in my power, of its different remains, as they were before the Society: Thirdly, I adduced a description of Wurmb's animal, as described in the Batavian Transictions, for the purpose of showing its identity with the Sumatran Orang Outang: Fourthly, I brought forward a description of the small Orang Outang of Borneo, for the purpose of showing its relationship to the two former aninals, and for the better examining the opinion of the Baron Cuvier, that it is only the young one of Wurmb's, and consequently of the Sumatran animal: and lastly, I quoted some notices of very large man-like apes contained in the works of the older travellers, and attempted to determine to which of these the Sumatran Orang should be referred. The essay which I read to the Society was prepared in haste, and from imperfect materials; and although it might, perhaps, be suited to its principal object, that of exciting inquiry, it was certainly mit for publication. For this reason, and because those who are likely to be chiefly interested in this communication will be better satisfied with facts than opinions, I shall at present limit myself to an account of those particulars of the appearance of the animal when alive which are best authenti-

* From the Asitutic Researches, vol. xv. p 489. 
cated, and of the circumstances that attended his capture, as they have been collected from the persons who took him, and conclude with a description of such parts of his body as are preserved in the museum of the Asiatic Society.

\section{Capture of the animal.}

The following short history of the circumstances under which the animal was found, and of the mode of taking him, is drawn up from accounts which were furnished to me either directly or indirectly by persons concerned in his capture. A boat party under the command of Messrs. Craygyman and Fish, officers of the brig Mary Anne Sophia having landed to procure water at a place called Ramboom near Touraman, on the N.W. coast of Sumatra, on a spot where there was much cultivated ground and but few trees, discovered on one of these a gigantic animal of the monkey tribe. On the approach of the party he came to the ground, and when pursued sought refuge in another tree at some distance, exhibiting as he moved, the appearance of a tall man-like figure covered with shining brown hair, walking erect with a waddling gait, but sometimes accelerating his motion with his hands, and occasionally impelling himself forward with the bough of a tree. His motion on the ground was plainly not his natural mode of progression, for even when assisted by his hands or a stick, it was slow and vacillating: it was necessary to see him amongst trees in order to estimate his agility and strength. On being driven to a small clump, he gained by one spring a very lofty branch, and bounded from one branch to another with the ease and alacrity of a common monkey. Had the country been covered with wood, it would have been almost impossible to prevent his escape, as his mode of travelling from one tree to another is described to be as rapid as the progress of a swift horse. Even amidst the few trees that were on the spot, his movements were so quick that it was very difficult to obtain a settled aim; and it was only by cutting down one tree after another, that his pursuers by confining him within a very limited range, were enabled to destroy him by several successive shots, some of which penetrated his body and wounded his viscera. Having received five balls, his exertions relaxed, and reclining exhausted on one of the branches of a tree, he vomited a considerable quantity of blood. The ammunition of the hunters being by this time expended, they were obliged to fell the tree in order to obtain him, and did this in full confidence that his power was so far gone that they could secure him without trouble, but were astonished as the tree was falling to see him effect his retreat 
to another, with apparently undiminished vigour. In fact, they were obliged to cut down all the trees before they could drive him to combat his enemies on the ground, against whom he still exhibited surprising strength and agility, although he was at length overpowered by numbers, and destroyed by the thrusts of spears and the blows of stones and other missiles. When nearly in a dying state, he seized a spear made of a supple wood which would have withstood the strength of the stoutest man, and shivered it in pieces; in the words of the narrator, he broke it as if it had been a carrot. It is stated by those who aided in his death, that the human-like expression of his countenance, and piteous manner of placing his hands over his wounds, distressed their feelings, and almost made them question the nature of the act they were committing. When dead, both natives and Europenns contemplated his figure with amazement. His stature at the lowest computation was upwards of six feet; at the highest it was nearly eight; but it will afterwards be seen that it was probably about seven. In the following description, which I give in the words of my informant, many of my readers will detect some of those external conformations which distinguish the young eastern Orang Outangs that have been seen in Europe. The only part of the description in which the imagination seems to have injured the fidelity of the portrait, regards the prominence of the nose and size of the eyes, neither of which are verified by the integuments of the animal's head. "The animal was nearly eight feet high, and had a well-proportioned body, with a fine broad expanded chest and narrow waist. His head also was in due proportion to his body; the eyes were large, the nose prominent, and the mouth much more capacious than the mouth of a man. His chin was fringed from the extremity of one ear to the other, with a beard that curled neatly on each side, and formed altogether an ornamental rather than a frightful appendage to his visage. His arms were very long even in proportion to his height, and in relation to the arms of men; but his legs were in some respects much shorter. His organs of generation were not very conspicuous, and seemed to be small in proportion to his size. The hair of his coat was smooth and glossy when he was first killed, and his teeth and appearance altogether indicated that he was young and in the full possession of his physical powers. Upon the whole," adds his biographer, "he was a wonderful beast to behold, and there was more in him to excite amazement than fear."

That this animal showed great tenacity of life is evident from his surviving so many dreadful wounds; and his pecu- 


\section{Dr. C. Abel on the Sumatran Orang Outang.}

liarity in this respect seems to have been a subject of intense surprise to all his assailants. In reference to this point it may be proper to remark, that after he had been carried on board ship, and was hauled up for the purpose of being skinned, the first stroke of the knife on the skin of the arm produced an instantaneous vibration of its muscles, followed by a convulsive contraction of the whole member. A like quivering of the muscles occurred when the knife was applied to the skin of the back, and so impressed Captain Cornfoot with a persuasion that the animal retained his sensibility, that he ordered the process of skinning to stop till the head had been removed.

It seems probable that this animal had travelled from some distance to the place where he was found, as his legs were covered with mud up to the knees, and he was considered as great a prodigy by the natives as by the Europeans. They had never before met with an animal like him, although they lived within two days journey of one of the vast and almost impenetrable forests of Sumatra. They seemed to think that his appearance accounted for many strange noises, resembling screams and shouts, and various sounds, which they could neither attribute to the roar of the tiger, nor to the voice of any other benst with which they were familiar. What capability the great Orang Outang may possess of nttering such sounds does not appear, but this belief of the Malays may lead to the capture of other individuals of his species, and to the discovery of more interesting particulars of his conformation and habits.

The only material discrepancy which I can detect in the different accounts which have been given of this animal, regards his height, which in some of them is vaguely stated at from above six feet to nearly eight. Captain Cornfoot however, who favoured me with a verbal description of the animal when brought on board his ship, stated that "he was a full head taller than any man on board, measuring seven feet in what might be called his ordinary standing posture, and eight feet when suspended for the purpose of being skinned."

The following measurements, which I have carefully made of different parts of the animal in the Society's Museum, go far to determine this point, and are entirely in favour of Captain Cornfoot's accuracy. The skin of the body of the animal dried and shrivelled as it is, measures in a straight line from the top of the shoulder to the part where the ancle has been removed, 5 feet 10 inches, the perpendicular length of the neck as it is in the preparation $3 \frac{1}{2}$ inches, the length of the head from the top of the forehead to the end of the chin 9 inches, and the length of the skin still attached to the foot from its. 
line of separation from the leg 8 inches:-we thus obtain 7 feet $6 \frac{1}{2}$ inches as the approximate height of the animal. The natural bending posture of the ape tribe would obviously diminish the height of the standing posture in the living animal, and probably reduce it to Captain Cornfoot's measurement of 7 feet, whilst the stretching that would take place when the animal was extended for dissection might as obviously increase his length to 8 feet.

\section{Description of the remains of the animal.}

HEAD.-The face of this animal with the exception of the beard is nearly bare, a few straggling short downy hairs being alone scattered over it, and is of a dark lead colour. The eyes are small in relation to those of man, and are about an inch apart: the eyelids are well fringed with lashes. The ears are one inch and a half in length, and barely an inch in breadth, are closely applied to the head, and resemble those of man, with the exception of wanting the lower lobe. The nose is scarcely raised above the level of the face, and is chiefly distinguished by two nostrils three-fourths of an inch in breadth, placed obliquely side by side. The mouth projects considerably in a mammillary form, and its opening is very large; when closed, the lips appear narrow, but are in reality half an inch in thickness. The hair of the head is of a reddish brown, grows from behind forwards, and is five inches in length. The beard is handsome and appears to have been curly in the animal's life-time, and approaches to a chesnut colour; it is about three inches long, springing very gracefully from the upper lip near the angles of the mouth, in the form of mustachios, whence descending, it mixes with that of the chin, the whole having at present a very wavy aspect. The face of the animal is much wrinkled.

Hands. - The palms of the hands are very long, are quite naked from the wrists, and are of the colour of the face. Their backs, to the last joint of the fingers, are covered with hair, which inclines a little backwards towards the wrists and then turns directly upwards. All the fingers have nails, which are strong, convex, and of a black colour; the thumb reaches to the first joint of the fore-finger.

Feet.-The feet are covered on the back with long brown hair to the last joint of the toes: the great toe is set on nearly at right angles to the foot, and is relatively very short. The original colour of the palms of the hands and the soles of the feet is somewhat uncertain, in consequence of the effect of the spirit in which they have been preserved.

New Series. Vol. 1. No. 3. March 182\%. 2 F Skin。 
SkIN.-The skin itself is of a dark leaden colour. The hair is of a brownish red, but when observed at some distance, has a dull, and in some places an almost black appearance; but in a strong light it is of a light red. It is in all parts very long; on the fore-arm it is directed upwards; on the upper arm its general direction is downwards, but from its length it hangs shaggy below the arm; from the shoulders it hangs in large and long massy tufts, which in continuation with the long hair on the back, seem to form one long mass to the very centre of the body. About the flanks the hair is equally long, and in the living animal must have descended below the thighs and nates. On the limits, however, of the lateral termination of the skin which must have covered the chest and belly, it is scanty, and gives the impression that these parts must have been comparatively bare. Round the upper part of the back it is also much thinner than elsewhere, and small tufts at the junction of the skin with the neck are curled abruptly upwards, corresponding with the direction of the hair at the back of the head.

In the dimensions which $I$ am about to give of the skin, I have stated that it measures from one extremity of the arm to another five feet eight inches; to this is to be added fifteen inches on each side for the hands and wrists, which will render the whole span of the animal equal to eight feet two inches.

The following are the measurements which I have made of the different parts :

\section{FACr.}

Length of the forehead from the commencement of the hair to a point between the eyes.

From between the eyes to the end of the nose . . . .

From the end of the nose to the mouth . . . . .

From the mouth to the setting on of the neck . .

Circumference of the mouth .

\section{SkrN.}

Greatest breadth about the centre of the skin . . .

Greatest length down the centre of the back .

Length from the extremity of one arm where it is se-

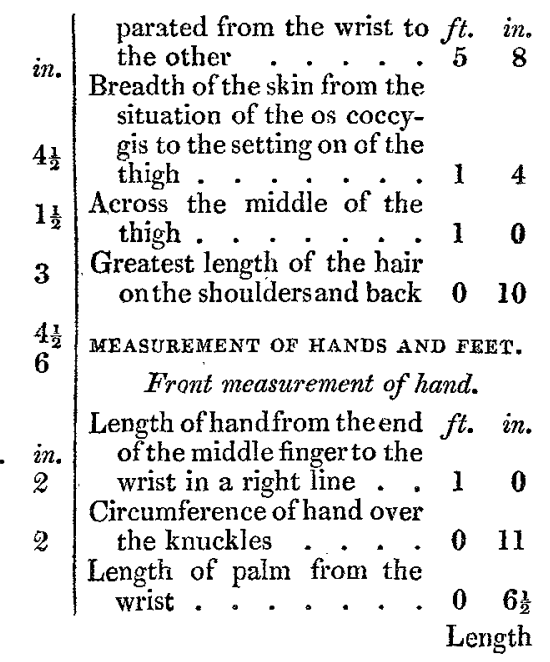


Lieut. G. Beaufoy's Astronomical Observations 182\%. 219

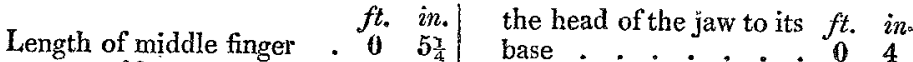

- - of fore finger $\quad 0 \quad 4 \frac{3}{4}$ Breadth of the ramus or as-

of little finger . . $\begin{array}{lll}0 & 4 \frac{4}{4} \\ \text { cending portion of the jaw }\end{array}$

$\begin{array}{cccc}- & 0 & 5 \\ \text { of ring finger } & \cdot & 0 & 21\end{array}$

Back measurement of hand.

Length of ring finger . . $\begin{array}{lll}0 & 63 \\ 4\end{array}$

- of middle finger $\cdot$\begin{tabular}{ccc}
0 & $6 \frac{3}{4}$ \\
\hline
\end{tabular}

- of little finger . . $0 \quad 5 \frac{3}{4}$

-

Front measurement of feet.

Length from the end of the heel to the end of the middle toe . . . . . 112

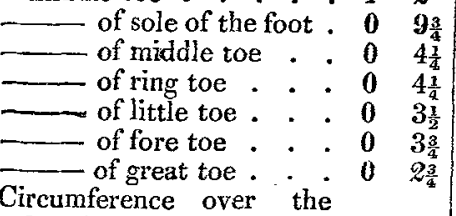

knuckles of the toes . . () $9 \frac{s}{4}$

Back measurement.

Length of middle toe $\quad$. $\quad \begin{array}{lll}0 & 6\end{array}$

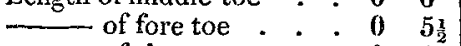

-

- - of little toe : . . 05

Measurement of the lower jaw.

Circumference of the jaw

round the chin. . .

Length of the ramus from

$0 \quad 11 \frac{1}{2}$ symphysis menti . . . $02 \frac{1}{2}$

MEASUREMENT OF THE teETh.

Number of teeth 32 ; namely, 2

Canine, 10 Grinders, ard 4 Incisive

Teeth in each jaw.

Canine Teeth.

Whole length of lower canine teeth . . . . 27

Greatest length of fang . . $\quad .2$

Smallest ditto . . . . . 1.6

Greatest length of the enamel or exposed part of the teeth. . . . .

Part exceeding the other teeth in length . . . . 4

Lateral breadth measured on a level with the jaw .

Breadth from beforeinwards

Incisive Teeth.

Whole length of the lateral $\quad 1.5$

Of enamel exposed . . $\quad \cdot \quad \cdot 7$

Breadth of cutting surface . $\quad .4$

Ditto of central teeth . . $\quad 4$

The front teeth of the upper jaw greatly resemble those of the lower, with the exception of the middle incisive teeth, which are twice the width of the lateral ones.

\section{Astronomical Observations 1827. By Lieut. GEoRgE Beaufoy, $R$. N.}

Bushey Heath, near Stanmore.

\section{ATITUDE $51^{\circ} 37^{\prime} 44^{\prime \prime} \cdot 3$ North. Longitude west in time $1^{\prime} 20^{\prime \prime} \cdot 93$.}

Observed transits of the moon, and moon-culminating stars over the middle of the transit instrument in sidereal time.

1827. Stars. Transits.

Jan. 3. 18 ג Piscium .......... 230 $33^{\prime} 14^{\prime \prime} \cdot 11$

3. 19 Piscium ............. $23 \quad 37 \quad 34.30$

3. Moon's First Limb...... $23 \quad 42445.05$ 